\title{
KLK11 wt Allele
}

National Cancer Institute

\section{Source}

National Cancer Institute. KLK11 wt Allele. NCI Thesaurus. Code C49716.

Human KLK11 wild-type allele is located within 19q13.3-q13.4 and is approximately $6 \mathrm{~kb}$ in length. This allele, which encodes kallikrein-11 protein, is involved in the proteolytic cleavage of substrates for both kallikrein and trypsin. 